\title{
Menimbang Kewenangan DPR dalam Penggunaan Hak Angket Pada Kasus Korupsi KTP Elektornik
}

\author{
Fahmi Ramadhan Firdaus \\ University of Jember, Indonesia \\ fhmiramadhan@gmail.com \\ Bayu Dwi Anggono \\ University of Jember, Indonesia \\ bayu_fhunej@yahoo.co.id
}

\begin{abstract}
In Indonesia, the control function of the House of Representatives (DPR) includes interpellation rights, inquiry rights and the right to express opinions. In 2017, the DPR's inquiry rights to the Corruption Eradication Commission (KPK) were considered unconstitutional because the law did not include the KPK as the object of the inquiry mechanism. However, the Constitutional Court (MK) in Decision Number 36 / PUU-XV / 2017 defined KPK as an executive so that this institution can be monitored through the inquiry mechanism. This court's decision, however, contradicts to the four previous decisions which classified KPK as an independent institution. This article examines the validity of the DPR's inquiry rights to the KPK by considering the DPR's inquiry rights as a form of a mechanism for mutual checks and balances to the other state institutions. In practice, there are both formal and material rules that must be fulfilled so that their implementation is legally valid and the DPR's inquiry rights to the KPK in cases of the electronic KTP corruption ignore these conditions. This article recommends that the DPR be careful when using inquiry rights as a monitoring mechanism.
\end{abstract}

KEYWORDS: Inquiry rights, House of Representatives, Corruption Eradication Commission.

Copyright $\odot 2019$ by Author(s)

This work is licensed under a Creative Commons Attribution-ShareAlike 4.0

International License. All writings published in this journal are personal views of the authors and do not represent the views of this journal and the author's affiliated institutions.

\section{HOW TO CITE:}

Firdaus, Fahmi Ramadhan \& Bayu Dwi Anggono. "Menimbang Kewenangan DPR dalam Penggunaan Hak Angket pada Kasus Korupsi KTP Elektronik" (2019) 6:1 Lentera Hukum 163-172. 


\section{PENDAHULUAN}

Artikel ini akan membahas pertentangan mengenai keabsahan Hak Angket yang digulirkan Dewan Perwakilan Rakyat terhadap Komisi Pemberantasan Korupsi yang dianggap salah sasaran. Dewan Perwakilan Rakyat termasuk kategori kekuasaan legislatif, di dalam melaksanakan fungsi dan kewenangannya seperti yang tercantum dalam Undang-Undang Dasar Negara Republik Indonesia Tahun 1945, konsep tersebut menganut teori Trias Politica yang dilahirkan oleh Montesquieu. ${ }^{1}$ DPR sebagai pelaksana kekuasaan legislatif, dalam menjalankan fungsi pengawasan, DPR mempunyai hak khusus yakni hak angket yang diatur pada pasal 20 A ayat (2) UUD 1945. Hak tersebut diberikan kepada Dewan Perwakilan Rakyat guna menjalankan mekanisme check and balances system. Tetapi, pelaksanaan hak angket ini seringkali dianggap sebagai hambatan dalam menjalankan penegakan hukum. Terakhir kali yang menyita perhatian publik adalah penggunaan hak angket yang ditujukan kepada Komisi Pemberantasan Korupsi yang disetujui oleh DPR di tahun 2017, yang dikhawatirkan pembentukan pansus angket tersebut digunakan untuk agenda tertentu yaitu mengintervensi bahkan cenderung melemahkan kewenangan serta fungsi KPK yang berkedudukan sebagai lembaga negara independen dan tidak bisa diintervensi oleh kekuasaan manapun ${ }^{2}$ dengan tujuan menjalankan fungsinya untuk mencegah dan memberantas korupsi di Indonesia.

Hak Angket adalah hak DPR dalam melaksanakan penyelidikan pada pelaksanaan undang-undang dan/atau kebijakan pemerintah yang mempunyai kaitan dengan hal penting, strategis, dan berdampak luas pada kehidupan bermasyarakat, berbangsa, bernegara yang diduga bertentangan dengan peraturan perundangundangan. Pengertian tersebut dijelaskan pada pasal 79 ayat (3) Undang-Undang No. 17 tahun 2014. Menurut penjabaran pasal tersebut, Hak Angket yang dapat dilaksanakan DPR limitatif hanya pada penyelidikan atas pelaksanaan undang-undang atau kebijakan pemerintah yang bersifat penting, strategis, berdampak luas dan bertentangan dengan peraturan perundang-undangan. Sekilas merujuk pada ketentuan tersebut, sesungguhnya KPK tidak dapat dijadikan objek angket oleh DPR, karena KPK merupakan lembaga independen dan tidak termasuk eksekutif.

\section{KEABSAHAN HAK ANGKET DEWAN PERWAKILAN RAKYAT TERHADAP KOMISI PEMBERANTASAN KORUPSI}

\section{A. Keabsahan Hak Angket}

Kronologis bergulirnya hak angket KPK dimulai pada 18 April 2017, Bermula dari rapat dengar pendapat DPR bersama KPK. Dalam rapat dengar pendapat ini, Komisi III meminta KPK agar membuka rekaman proses pemeriksaan BAP Miryam S. Haryani dan KPK menolak membuka hasil rekaman tersebut walaupun untuk mengklarifikasi

Charles De Montesquieu, Montesquieu: the Spirit of the Laws (Cambridge University Press, 1989).

Lihat Pasal 3 Undang-Undang No. 30 Tahun 2002 tentang Komisi Pemberantasan Tindak Pidana Korupsi. 
adanya indikasi-indikasi dalam penyelesaian kasus korupsi KTP elektronik yang menyeret beberapa nama anggota DPR. ${ }^{3}$

Keesokan harinya pada 19 April 2017, rapat dengar pendapat kembali dilanjutkan antara Komisi III dengan KPK. Dengan sikap yang sama, KPK tetap menolak untuk membuka rekaman pemeriksaan BAP Miryam. Benny K Harman selaku pimpinan Komisi III, mendorong komisinya untuk menggunakan upaya paksa melalui penggunaan hak angket. Beberapa fraksi setuju digunakannya hak angket, fraksi yang setuju diantaranya Gerindra, Golkar, PDIP, Demokrat, PPP dan, NasDem. Sedangkan, PAN, PKS, dan Hanura memilih untuk berkoordinasi terlebih dahulu dengan pimpinan fraksi dan PKB belum ada sikap resmi karena absen saat rapat berlangsung. ${ }^{4}$

Pada 20 April 2017, Anggota Komisi III DPR Arsul Sani menyatakan pihaknya tidak hanya akan menggulirkan hak angket terhadap KPK. Komisi III juga melakukan penyelidikan terhadap laporan hasil pemeriksaan (LHP) KPK oleh BPK yang diduga terdapat penyimpangan dan tidak wajar. ${ }^{5}$ Seminggu kemudian pada 26 April 2017, dalam sidang paripurna disebutkan surat masuk usulan mengenai hak angket belum dikirimkan oleh Komisi III. Untuk menindaklanjutinya pimpinan DPR beserta pimpinan fraksi melaksanakan rapat badan musyawarah dan memutuskan pembahasan hak angket KTP elektronik dilaksanakan dalam sidang paripurna esok hari. Fahri Hamzah menyebutkan 8 fraksi setuju terhadap pengusulan hak angket. Tetapi Demokrat, Gerindra dan PKB berubah sikap untuk menolak hak angket. Keesokan harinya PKS menolak keberadaan hak angket terkait kasus KTP elektronik.

Puncaknya pada 28 April 2017, Rapat paripurna penutupan masa sidang sebelum masuk masa reses anggota DPR dengan agenda pembahasan pengajuan hak angket. Dinamika usulan hak angket ini membuat pimpinan DPR secara mendadak melangsungkan rapat informal menjelang sidang paripurna dimulai. Setelah sidang paripurna dimulai, perwakilan Komisi III DPR M. Taufiqulhadi, membacakan usulan hak angket tersebut. Kemudian timbul interupsi dari beberapa anggota DPR. Fraksi PKB, dan Demokrat sepakat untuk menolak hak angket. Masinton Pasaribu selaku anggota Fraksi PDIP mengkritik sejumlah fraksi yang tidak konsisten dari yang awalnya sepakat berubah menjadi menolak. Kemudian secara sepihak Fahri Hamzah yang merupakan pimpinan sidang saat itu mengetok palu yang berarti usulan hak angket disetujui dan tidak menanggapi interupsi dari anggota yang tidak sepakat. Akibat keputusan tersebut, tidak sedikit anggota DPR yang walk out, termasuk Fraksi Gerindra. Terkait pembentukan pansus hak angket KPK, akan dilaksanakan setelah masa reses berakhir. ${ }^{6}$

Ada dua hal yang menjadi tolak ukur apakah keputusan suatu lembaga negara itu

\footnotetext{
Elza Astari Retaduari, "Perjalanan Hak Angket KPK hingga Disetujui Paripurna DPR", online: detiknews 〈https://news.detik.com/read/2017/04/28/130354/3486565/10/perjalanan-hak-angketkpk- hingga-disetujui-paripurna-dpr>.

Ibid.

Ibid.

Ibid.
} 
sah atau tidak, yaitu prosedur (formal) dan substansi (materi). ${ }^{7}$ Dalam konteks ini, adanya dugaan bahwa hak angket DPR terhadap KPK merupakan cacat hukum. Secara prosedur, menurut Undang-undang Nomor 17 Tahun 2014 ada 3 tahap pelaksanaan hak angket, yaitu: pengusulan, pembahasan, dan pengambilan keputusan.

Dalam tahap pengusulan, hak angket diajukan oleh minimal 25 orang anggota DPR dan lebih dari 1 fraksi. Pengajuan wajib disertai dengan dokumen yang memuat materi kebijakan atau implementasi undang-undang yang akan diselidiki beserta alasan penyelidikan. Setelah diajukan oleh minimal 25 orang anggota DPR, kemudian perwakilan mengusulkan angket kepada Pimpinan DPR. Lalu Pimpinan DPR akan menindaklanjutinya dengan Rapat Paripurna dan membahas usulan tersebut. Jika Rapat Paripurna dihadiri lebih dari setengah jumlah anggota DPR kemudian usulan tersebut disetujui oleh mereka, maka usul akan ditindaklanjuti dalam pelaksanaan oleh DPR.

Setelah disetujui dalam Rapat Paripurna, langkah selanjutnya DPR membentuk panitia angket yang merupakan panitia khusus untuk tahap pelaksanaan. Anggota dari Panitia Angket berasal dari semua unsur fraksi di DPR. Panitia angket memiliki waktu selama 60 hari untuk melaksanakan penyelidikan. ${ }^{8}$ Setelah waktu yang ditentukan maka pansus angket berkewajiban melaporkan temuannya dalam Rapat Paripurna. Kemudian tahap pengambilan keputusan. Kuorum dalam Rapat Paripurna untuk pengambilan keputusan hasil kerja Panitia Angket, jumlahnya sama dengan kuorum awal dalam pengajuannya, yaitu jika dihadiri lebih dari setengah jumlah keseluruhan anggota DPR dan disetujui oleh lebih dari setengah dari jumlah anggota DPR yang hadir.

Dalam pelaksanannya prosedur tersebut tidak dilaksanakan oleh DPR, yang pertama dalam tahap pengusulan. Menurut Pasal 199 UU No. 17 tahun 2014 tentang MD3, Hak angket wajib diajukan minimal 25 anggota DPR dan lebih dari 1 fraksi (ayat 1). Lalu harus disepakati dalam rapat paripurna DPR yang dihadiri lebih dari setengah jumlah anggota DPR kemudian keputusan disepakati dengan persetujuan lebih dari setengah jumlah anggota DPR yang hadir (ayat 3). Sebagai ketua sidang paripurna yang dilaksanakan pada 28 April 2017 yang mengesahkan hak angket KPK. Nyatanya Fahri Hamzah tidak menjalankan mekanisme tersebut. Padahal hanya disetujui oleh 25 anggota DPR dari 8 fraksi di DPR. Parahnya lagi Fahri Hamzah tidak memberikan ruang berpendapat bagi anggota yang menolak hak angket yang diusulkan sehingga terjadi walk out dan tidak mengikuti voting oleh 3 fraksi yaitu Fraksi PKB, Fraksi Demokrat, dan Fraksi Gerindra. Kesimpulannya, hak angket KPK oleh DPR RI dapat dikatakan cacat secara prosedural karena tidak sesuai dengan aturan yang tercantum dalam UU No. 17 Tahun 2014 sehingga keabsahan hak angket KPK masih menimbulkan pertanyaan.

Kedua, bukti lain cacat prosedur penerapan Hak Angket KPK adalah panitia

Koentjoro Purbopranoto, Beberapa Catatan Hukum Tata Pemerintahan dan Peradilan Administrasi Negara (Alumni, 1975) at 48-49.

8 Lihat Pasal 206 Ayat (1) Undang-Undang Nomor 17 Tahun 2014 tentang MPR, DPR,DPD dan DPRD (MD3). 
angket harus diisi oleh seluruh fraksi yang ada di dalam DPR. ${ }^{9}$ Padahal sampai akhir,ada 3 fraksi yang tidak masuk dalam panitia angket, yaitu Fraksi Demokrat, PKB, dan PKS. Hal ini juga menunjukkan adanya penyimpangan prosedur lainnya.

Ketiga, pengambilan keputusan persetujuan hak angket KPK tidak dijalankan menurut mekanisme yang diatur dalam Undang-Undang Nomor 17 Tahun 2014 tentang MPR, DPR, DPD, dan DPRD (UU MD3). Seperti yang disebutkan pada pasal 199 ayat (3) yang mengatur bahwa usul hak angket oleh pengusul (minimal 25 anggota DPR lebih dari 1 fraksi) dapat dikatakan sebagai hak angket DPR jika disetujui oleh lebih dari setengah jumlah anggota DPR yang hadir dalam rapat paripurna.

Mekanisme pengambilan suara atau voting secara terbuka merupakan cara untuk dapat mengetahui bahwa lebih dari setengah jumlah anggota DPR yang hadir menyetujui pelaksanaan hak angket. Setiap anggota DPR yang hadir dalam rapat paripurna mempunyai hak suara (one man one vote) untuk memutuskan sikap setuju atau tidak setuju terhadap usulan penggunaan hak angket tersebut, dalam hal ini hak angket KPK. ${ }^{10}$

Prosedur pengambilan keputusan persetujuan terhadap hak angket KPK yang dilaksanakan hanya melalui penjelasan pengusul hak angket, dan dilanjutkan pengambilan keputusan langsung secara sepihak oleh pimpinan sidang paripurna tanpa melalui mekanisme pengambilan suara terhadap seluruh anggota DPR yang hadir dalam rapat paripurna, jelas tindakan tersebut menyalahi ketentuan Pasal 199 ayat (3) UU MD3. Terdapat indikasi pelanggaran substansi terkait digulirkannya hak angket DPR terhadap KPK. Dalam rangka fungsi pengawasan DPR memliki 3 (tiga) hak antara lain hak interpelasi, hak angket, dan hak menyatakan pendapat. Terkait pengertian dan siapa saja yang termasuk kedalam subjek angket diatur pada Pasal 79 ayat (3) UU MD3. Pengertian hak angket tercantum pada Pasal 79 ayat (3) UU MD3 yang berbunyi:

"Hak angket sebagaimana dimaksud pada ayat (l) huruf b adalah hak DPR untuk melakukan penyelidikan terhadap pelaksanaan suatu undang-undang dan/atau kebijakan Pemerintah yang berkaitan dengan hal penting, strategis, dan berdampak luas pada kehidupan bermasyarakat, berbangsa, dan bernegara yang diduga bertentangan dengan peraturan perundang-undangan."

Lantas siapakah pemerintah yang disebutkan pada Pasal 79 ayat (3) UU MD3 tersebut, hal ini sudah dituangkan dalam penjelasan Pasal 79 ayat (3) yaitu: Pelaksanaan suatu undang-undang dan/atau kebijakan Pemerintah dapat berupa kebijakan yang dilaksanakan sendiri oleh Presiden, Wakil Presiden, menteri negara, Panglima TNI, Kapolri, Jaksa Agung, atau pimpinan lembaga pemerintah nonkementerian.

Jika merujuk pada penjelasan Pasal 79 ayat (3) UU MD3, jelas KPK tidak termasuk kedalam klasifikasi siapakah Pemerintah itu. Untuk mengetahui apakah KPK

9 Lihat Pasal 201 Ayat (2) Undang-Undang Nomor 17 Tahun 2014 tentang MPR, DPR,DPD dan DPRD (MD3).

10 Bayu Dwi Anggono, "Angket DPR untuk KPK Langgar Konstitusi", online: detiknews`https://news.detik.com/read/2017/05/04/130644/3491659/103/angket-dpr-untuk-kpklanggar-konstitusi>. 
termasuk kedalam kualifikasi Lembaga Pemerintah Non Kementerian (LPNK) dapat berpedoma kepada peraturan yang mangatur lembaga mana saja yang dapat dikategorikan sebagai LPNK.

Peraturan Presiden Nomor 4 Tahun 2013 tentang Perubahan kedelapan atas Keputusan Presiden Nomor 110 Tahun 2001 tentang Unit Organisasi dan Tugas Eselon I Lembaga Pemerintah Non Kementerian merupakan regulasi yang mengatur LPNK hingga saat ini. Sebagai catatan, pada Pasal 1 Perpres 4/2013 memberikan batasan dan mengkategorikan lembaga mana saja yang termasuk LPNK. Ada 14 lembaga yang termasuk kedalam LPNK antara lain: Lembaga Administrasi Negara (LAN); Arsip Nasional Republik Indonesia (ANRI); Badan Kepegawaian Negara (BKN); Perpustakaan Nasional Republik (PERPUSNAS); Badan Standardisasi Nasional (BSN); Badan Pengawas Tenaga Nuklir (BAPETEN); Badan Tenaga Nuklir Nasional (BATAN); Lembaga Sandi Negara (LEMSANEG); Badan Kependudukan dan Keluarga Berencana Nasional (BKKBN); Lembaga Penerbangan Antariksa Nasional (LAPAN); Badan Pengawasan Keuangan dan Pembangunan (BPKP); Lembaga Ilmu Pengetahuan Indonesia (LIPI); Badan Pengkajian dan Penerapan Teknologi (BPPT); dan Badan Pengawasan Obat dan Makanan (BPOM).

Jika melihat penjabaran Pasal 1 Perpres 4/2013 sudah sangat jelas KPK tidak masuk dalam LPNK. Karena KPK tidak dikategorikan sebagai LPNK dan juga dalam klasifikasi Presiden, Wakil Presiden, menteri negara, Panglima TNI, Kapolri, atau Jaksa Agung sehingga KPK tidak memenuhi pengertian pemerintah menurut penjelasan Pasal 79 ayat (3) UU MD3. Pihak yang mengusulkan hak angket berpandangan, jika hak angket DPR bukan hanya sebatas kebijakan pemerintah tetapi juga dapat digunakan sebagai pengawasan untuk penyelidikan terhadap pelaksanaan undang-undang yang dilaksanakan lembaga negara. Sehingga pihak pengusul berkesimpulan meski KPK tidak termasuk kedalam kategori pemerintah, namun KPK merupakan lembaga negara negara pelaksana undang-undang sehingga berdasarkan argumen tersebut KPK dapat dijadikan subjek angket.

Namun, pandangan dari pengusul tidak dapat diterima begitu saja. Karena menurut ketentuan Pasal 24 ayat (3) UUD 1945 KPK memiliki kedudukan sebagai badan-badan lain yang berkaitan fungsinya dengan kekuasaan kehakiman. Menurut Pasal 24 ayat (3) UUD 1945 mengatur bahwa badan-badan lain yang fungsinya berkaitan dengan kekuasaan kehakiman diatur dalam undang-undang. Hal ini sesuai dengan Pasal 6 huruf c Undang-Undang Nomor 30 Tahun 2002 tentang KPK yang menjelaskan bahwa salah tugas KPK adalah untuk melakukan penyelidikan, penyidikan, dan penuntutan terhadap tindak pidana korupsi, sehingga KPK masuk kedalam kategori Pasal 24 ayat (3) UUD 1945. ${ }^{\text {ll }}$

Sebagai badan yang fungsinya berkaitan dengan kekuasaan kehakiman. Adanya KPK tidak dapat dipisahkan terhadap jaminan independensi kekuasaan kehakiman di Pasal 24 ayat (1) UUD 1945 yang berbunyi: Kekuasaan kehakiman merupakan kekuasaan yang merdeka untuk menyelenggarakan peradilan guna menegakkan hukum

$11 \quad$ Ibid. 
dan keadilan.

Pasal 24 ayat (1) UUD 1945 memberikan jaminan kepada KPK berupa kemerdekaan dalam menjalankan wewenangnya, sama halnya jaminan kepada Mahkamah Agung dan badan peradilan di bawahnya serta Mahkamah Konstitusi sebagai pelaksana kekuasaan kehakiman yang bebas dari pengaruh dan intervensi cabang kekuasaan mana pun dalam menjalankan kewenangannya. Independensi KPK juga diatur di dalam Undang-Undang KPK, tepatnya pada Pasal 3 yang berbunyi: Komisi Pemberantasan Korupsi adalah lembaga negara yang dalam melaksanakan tugas dan wewenangnya bersifat independen dan bebas dari pengaruh kekuasaan mana pun. Hal ini berkesinambungan dengan Pasal 24 ayat (1) UUD 1945.

Penggunaan hak angket DPR terhadap KPK selain tidak sesuai dengan subjek yang seharusnya dikenakan angket, juga sebagai upaya DPR untuk melakukan intervensi terhadap pelaksana kekuasaan kehakiman dan badan-badan lain yang fungsinya berkaitan dengan KPK.

Adanya indikasi cacat formil dan cacat materiil dalam pelaksanaan hak angket DPR terhadap KPK, sehingga hak angket ini bisa dianggap batal demi hukum dan apapun hasil atau rekomendasi pansus angket KPK. KPK tidak mempunyai kewajiban untuk melaksanakan rekomendasi pansus. Namun apabila DPR tetap memaksakan kehendaknya agar KPK menindaklanjuti hasil pansus angket. Maka DPR sesungguhnya telah melanggar UUD 1945. ${ }^{12}$ DPR telah salah sasaran dan tidak pada tempatnya dalam menggunakan hak angket.

\section{B. Implikasi Pengajuan Hak Angket}

Ada 4 aspek yang menjadi rekomendasi pansus angket KPK sebagai hasil mereka bekerja selama batas waktu yang ditentukan. Aspek yang dimaksud antara lain, aspek kelembagaan, aspek kewenangan, aspek tata kelola anggaran, dan aspek Sumber Daya Manusia (SDM). ${ }^{13}$ Pertama dalam aspek kelembagaan, KPK harus menyempurnakan struktural organisasi sehingga sesuai dengan tugas dan kewenangannya seperti tercantum dalam Undang-Undang KPK atara lain, koordinasi, supervisi, penindakan, pencegahan, dan monitoring. Kedua, KPK harus lebih meningkatkan upaya membangun kerjasama dengan lembaga penegak hukum serta lembaga lain yang berkaitan dengan tugas dan kewenangan KPK seperti BPK, LPSK, PPATK, Komnas HAM, dan pihak perbankan, sehingga pemberantasan korupsi berjalan maksimal karena integrasi antar lembaga negara. Ketiga, KPK diminta untuk membentuk lembaga pengawas independen yang beranggotakan unsur internal dan eksternal KPK dengan kriteria anggota merupakan tokoh-tokoh yang berintegritas. Pembentukannya diserahkan menurut mekanisme internal KPK.

Dalam aspek kewenangan, pansus merekomendasikan yang pertama, agar KPK lebih meningkatkan koordinasi dan melakukan supervisi dengan Kepolisian dan

12 Ibid.

13 Joko Panji Sasongko, "Kerja Pansus Angket KPK Selesai dengan Empat Rekomendasi", online: nasional 〈https://www.cnnindonesia.com/nasional/20180214104633-32-276096/kerja-pansus-angketkpk-selesai-dengan-empat-rekomendasi>. 
Kejaksaan sebagai upaya Trigger Mechanism. Kedua, KPK diharapkan untuk mempertimbangkan prinsip HAM atau due process of law dalam menjalankan tugas penyelidikan, penyidikan, dan penuntutan, serta berpedoman pada peraturan perundang-undangan lainnya, seperti Undang-Undang Perlindungan Saksi dan Korban dan Undang-Undang tentang HAM. Ketiga, mendorong KPK agar membangun sistem pencegahan korupsi yang sistematis sehingga maksimal dalam usaha agar korupsi tidak terulang kembali yang akan menyelamatkan keuangan negara. Dalam segi anggaran, Pansus Angket merekomendasikan, pertama, agar KPK mengoptimalkan dan memperbaiki tata kelola anggarannya menurut hasil rekomendasi dari BPK.

Kedua, DPR mengupayakan usaha untuk meningkatkan anggaran KPK dalam penggunaan anggaran untuk fungsi pencegahan, seperti pendidikan, sosialisasi, dan kampanye antikorupsi sehingga pemberantasan korupsi dapat berjalan optimal. Terakhir, dari aspek manajemen SDM, Pansus Angket menghasilkan rekomendasi KPK untuk, pertama, memperbaiki menajerial SDM berdasarkan peraturan perundangundangan di bidang SDM atau kepegawaian. Kedua, KPK diminta untuk transparan dan terukur dalam proses pengangkatan, promosi, mutasi, rotasi, sampai pemberhentian SDM di KPK berpedoman pada undang-undang yang mengatur tentang aparatur sipil negara, Kepolisian, dan Kejaksaan. Asosiasi Pengajar Hukum Tata Negara-Hukum Administrasi Negara (APHTN-HAN) dan Pusat Studi Konstitusi (PUSaKO) Fakultas Hukum Universitas Andalas merilis kajian yang ditandatangani oleh sebanyak 132 Guru Besar Hukum dari berbagai universitas, mengenai hak angket DPR terhadap KPK yang menyatakan hal tersebut merupakan cacat hukum. Karena, DPR telah bertindak inkonstitusional dan salah sasaran. ${ }^{14}$

\section{KESIMPULAN}

Hak Angket DPR terhadap KPK melanggar prinsip independensi yang dimiliki oleh KPK, selain itu hak angket tesebut cacat hukum karena tidak memenuhi syarat formil dan materil, karena panitia angket dalam tahap pengusulan, pelaksanaan sampai pengambilan keputusan tidak sesuai dengan mekanisme ketentuan dalam UndangUndang Nomor 17 Tahun 2014 tentang MPR, DPR, DPD, dan DPRD. Dalam segi materiil, dinilai KPK bukan merupakan cabang kekuasaan eksekutif yang dapat diangket seperti yang disebutkan dalam penjelasan pasal 79 ayat (3) Undang-Undang No.17 tahun 2014. Namun KPK mempunyai kedudukan independen dalam perkembangan teori ketatanegaraan modern dan menjalankan fungsi yang berkaitan dengan kekuasaan kehakiman namun bukan pelaku kekuasaan kehakiman. Pasal 24 ayat (3) UUD NRI 1945 juga mengatur mengenai badan-badan yang berkaitan dengan fungsi kekuasaan kehakiman dan KPK termasuk didalamnya apabila melihat fungsi dan kewenangannya, Berkaitan dengan fungsi kekuasaan kehakiman maka tidak dilepaskan

14 Fachrur Rozie, "132 Guru Besar Hukum Sebut Hak Angket KPK Cacat", online: liputan6.com`https://www.liputan6.com/news/read/2990852/132-guru-besar-hukum-sebut-hakangket-kpk-cacat>. 
pada jaminan kemerdekaan dari intervensi kekuasaan manapun atau independen. Independensi KPK juga ditegaskan pada Pasal 3 Undang-Undang No. 30 Tahun 2002 bahwa Komisi Pemberantasan Korupsi adalah lembaga negara yang dalam melaksanakan tugas dan wewenangnya bersifat independen dan bebas dari pengaruh kekuasaan mana pun.

Saran bagi Dewan Perwakilan Rakyat, agar lebih berhati-hati dalam menggunakan hak angket sebagai mekanisme pengawasan, harus ada kajian lebih komperehensif dan mempertimbangkan dampak kedepannya. Penggunaan hak angket harus sesuai dengan ketentuan perundang-undangan yang berlaku baik secara formil dan materiil. Mahkamah Konstitusi harus lebih konsisten dan taat asas dalam memutuskan sebuah perkara mengingat sifat putusannya yang final dan binding sehingga tidak dimungkinkan upaya hukum kembali serta harus mempertimbangkan putusan-putusan yang telah diputus sebelumnya.

\section{DAFTAR PUSTAKA}

Anggono, Bayu Dwi. Perkembangan Pembentukan Undang-Undang di Indonesia (Konstitusi Press, 2014).

De Montesquieu, Charles. Montesquieu: The Spirit Of The Laws (Cambridge University Press, 1989).

Mochtar, Zainal Arifin. Lembaga Negara Independen Dinamika Perkembangan dan Urgensi Penataannya Kembali Pasca-Amandemen Konstitusi (PT. Rajagrafindo Persada, 2016).

Moh Mahfud M D. Dasar dan Struktur Ketatanegaraan Indonesia, cet. 2, edisi revisi ed (Jakarta: Rineka Cipta, 2001).

Purbopranoto, Koentjoro. Beberapa Catatan Hukum Tata Pemerintahan dan Peradilan Administrasi Negara (Alumni, 1975).

Anggono, Bayu Dwi. “Angket DPR untuk KPK Langgar Konstitusi”, online: detiknews 〈https://news.detik.com/read/2017/05/04/130644/3491659/103/angket-dpr-untuk-kpklanggar-konstitusi>.

Ibrahim, Gibran Maulana. "Ini Sederet Alasan DPR Gulirkan Hak Angket KPK", online: detiknews 〈https://news.detik.com/read/2017/04/28/152648/3486828/10/inisederet-alasan-dpr-gulirkan-hak-angket-kpk>.

Jun 2017, Fachrur Roziel4 \& 18:53 Wib. "132 Guru Besar Hukum Sebut Hak Angket KPK Cacat", online: liputan6.com 〈https://www.liputan6.com/news/read/2990852/132-guru- besar-hukum-sebuthak-angket-kpk-cacat>. 
172 | Menimbang Kewenangan DPR dalam Penggunaan Hak Angket pada Kasus Korupsi KTP Elektronik

This page is intentionally left blank 